\title{
Evaluation of prenatal care in Primary Health Care in Brazil
}

Ana Carolina Cunha 1

https://orcid.org/0000-0003-1580-9470

Josimari Telino de Lacerda 2

(iD https://orcid.org/0000-0002-1992-4030

Mônica Teresa Ruocco Alcauza 3

https://orcid.org/0000-0002-7501-1818

Sônia Natal 4

D https://orcid.org/0000-0001-6155-4785

1-4 Programa de Pós-graduação em Saúde Coletiva. Universidade Federal de Santa Catarina. Campus Reitor João David Ferreira Lima, s/n. Florianópolis, SC, Brasil. CEP 88040-900. E-mail: enfer.anacunha@gmail.com

\begin{abstract}
Objectives: to evaluate prenatal care in Primary Care by identifying the aspects that influence structural and operational adequacy.

Methods: evaluation research with analysis of 4,059 municipalities that joined the 2nd cycle of the Program for Improving Access and Quality in Primary Care in 2013-2014. The evaluative model composed of 19 indicators grouped in structural aspects and operational aspects dimensions was validated in a consensus conference. Data analysis was descriptive, with the issuance of value judgment.

Results: in structural aspects, 32.6\% of the municipalities presented adequacy, whilst in operational ones, only $24.1 \%$. In the general prenatal evaluation, less than a quarter $(24.6 \%)$ of the municipalities was adequate, those with up to 10 thousand inhabitants had a higher percentage of adequacy (41.6\%). The South region presented adequacy of $33.8 \%$, considering all sizes.

Conclusions: most municipalities presented low adequacy in prenatal care, with better performance of structural aspects. Smaller municipalities presented better results in all analyzed items. Structural aspects and general evaluation of prenatal care are highlighted in the South region. Adequate attention to prenatal care needs to be comprehensive and equitable, with the strengthening of regional networks geared towards social inclusion.
\end{abstract}

Key words Health evaluation, Primary health care, Quality assurance, Health care 


\section{Introduction}

Prenatal care includes health education actions, risk identification, prevention and treatment of complications and diseases, requiring planning and structuring to guarantee access and continuity of care with effective comprehensiveness of care, in order to promote mother and child health. 1,2

Low-risk prenatal care is configured as one of the main programmatic actions carried out in Primary Care (PC). The whole process of women's health care is influenced by the social, economic and cultural context of the environment in which pregnant women and concepts live. Structural and operational aspects must be guaranteed for continuous and quality monitoring, with humanized care to pregnancy. Prenatal care involves a warm relationship and the systematic follow-up of the pregnant woman contributes to the early detection of diseases and gestational risk, preparation for childbirth and establishment of a bond with motherhood. 3

The inadequacy of prenatal care actions is associated with negative effects such as prematurity and low birth weight, in addition to increased risk of fetal and maternal death, hospitalizations in intensive care units, postpartum depression and anxiety, and successive pregnancies in a short time.4,5

In Brazil, there has been an increase in coverage of prenatal care in the last years in most of the country, 6,7 coinciding with the institutionalization of actions aimed at the comprehensiveness of care, proposed from different national programs in the period from 1984 to 2011. Despite this, the challenges persist with a high level of inadequacy of actions, endangering maternal and child health. 6

High child mortality rates, with a higher concentration of deaths in the early neonatal components, 2,8 and the still high maternal mortality rate (58 maternal deaths out of 100 thousand live births), with expressive disparities in the country, ${ }^{9}$ reinforce the existence of failures in the care provided.

The institutionalization of prenatal care evaluation is a fundamental strategy for the improvement of quality with consequent reduction of maternal and infant morbimortality, 10 since it reveals and produces subsidies for awareness and confrontation with failures, reviewing public policies and managerial and procedural adaptations, in order to respond more adequately and with immediate solution the needs of this population group. Studies that evaluated prenatal care with national coverage observed inadequacies in relation to the recommended $6,10,11$ and had as a unit of analysis users 11 and PC6,10 teams, and it was necessary to advance in the aspects of municipal management responsibility.

Accordingly, the objective of this study was to evaluate prenatal care in PC by identifying the aspects that influence structural and operational adequacy, with a focus on management, having the Brazilian municipalities as a unit of analysis.

\section{Methods}

Evaluative study, of quantitative based approach of the low risk prenatal care having as analysis units the Brazilian municipalities that participated in the external evaluation of the Program for Improving Access and Quality of Primary Care (PMAQ - AB), in $2013-2014$.

The municipalities that have joined with at least $80 \%$ of the teams in the $2^{\text {nd }}$ cycle of PMAQ $-A B$ were included, and responded to modules I and II. The sample consisted of 4,059 municipalities, 19,849 Basic Health Units (BHU) and 24,626 participants in the Family Health Strategy (FHS).

The theoretical-logical model and the matrix of analysis and judgment are based on documental and bibliographic research pertinent to the theme. The main documents used were the ordinance that established the Stork Network (2011) and the Technical Standards and Manuals of the series of Notebooks of Primary Care $n^{\circ} 18, n^{\circ} 26$ and $n^{\circ} 32$ : HIV/Aids, hepatitis and other sexually transmitted diseases (2006), Sexual health and reproductive health (2010) and Attention to low risk prenatal care (2013), respectively.

The evaluative model was validated in Consensus Conference, in two stages: distance and face-to-face meeting. A group of eight experts from the field of women's health and/or public policy evaluation participated in the two phases. The model was emailed and the experts were invited to give their full, partial agreement or disagreement within 15 days. The researchers consolidated the answers and cases of discordance were the subject of debate in the face-to-face meeting. All suggestions were included from consensus.

The analysis and judgment matrix has two dimensions, six sub-dimensions, 19 indicators and 30 measures. The "structural aspects" dimension analyzes the conditions of infrastructure, human resources and standardization of care that give the conditions for the teams to carry out their activities. The "operational aspects" dimension analyzes the activities carried out by the teams, focusing on the organization of care, promotion and prevention and follow-up (Tables 1 and 2). 
Table 1

Analysis and judgment matrix of structural aspects of the evaluation of prenatal care in Primary Care. Brazil, 2017.

\begin{tabular}{|c|c|c|c|}
\hline Evaluative matrix & Measures & \multicolumn{2}{|c|}{ Judgment Parameters } \\
\hline \multicolumn{4}{|l|}{ Structural aspects } \\
\hline Infrastructure & & $\geq 90 \%=$ adequate $(1.0)$ & \\
\hline \multirow[t]{2}{*}{ Adequacy of the physical space } & $\%$ BHU with nursing office and waiting & 89 to $75 \%$ = minimally adequate $(0.5)$ & \\
\hline & room & $<75 \%=$ inadequate $(0.0)$ & \\
\hline \multirow{7}{*}{$\begin{array}{l}\text { Materials and equipment for prenatal } \\
\text { care }\end{array}$} & $\%$ UBS that makes available a pregnant & $\geq 90 \%$ = adequate & \\
\hline & woman's booklet & 89 to $75 \%$ = minimally adequate; & Both adequate= adequate $(1.0)$ \\
\hline & & $<75 \%=$ inadequate & Both inadequate $=$ inadequate $(0.0)$ \\
\hline & & & Other situations $=$ minimally adequate \\
\hline & $\%$ BHU with availability of equipment & $\geq 90 \%=$ adequate & $(0.5)$ \\
\hline & and furniture for prenatal care & 89 to $75 \%$ = minimally adequate; & \\
\hline & & $<75 \%=$ inadequate & \\
\hline \multirow[t]{6}{*}{ Inputs and medicines } & $\%$ BHU with supply of important & $\geq 90 \%=$ adequate & Both adequate $=$ adequate $(1.0)$ \\
\hline & vaccines for the prenatal period & 89 to $75 \%$ = minimally adequate; & Both inadequate $=$ inadequate $(0.0)$ \\
\hline & & $<75 \%=$ inadequate & Other situations $=$ little adequate $(0.5)$ \\
\hline & $\%$ BHU with availability of essential & $\geq 90 \%=$ adequate & \\
\hline & medicines for the gestational period & 89 to $75 \%$ = minimally adequate; & \\
\hline & & $<75 \%=$ inadequate & \\
\hline \multicolumn{4}{|l|}{ Human resources } \\
\hline \multirow[t]{13}{*}{ Adequacy of staff } & $\%$ FHS with complete minimum health & Dichotomous analysis, according to population & Both adequate $=$ adequate $(1.0)$ \\
\hline & staff * & size. Parameter to "adequate" & Both inadequate $=$ inadequate $(0.0)$ \\
\hline & & Up to 50 thousand inhab. $=100 \%$ & Other situations $=$ little adequate $(0.5)$ \\
\hline & & $>50$ to 100 thousand inhab. $=90 \%$ & \\
\hline & & $>100$ to 500 thousand inhab. $=85 \%$ & \\
\hline & & $>500$ thousand inhab. $=60 \%$ & \\
\hline & $\%$ FHS with oral health* & Dichotomous analysis, according to population & \\
\hline & & size. Parameter to "adequate" & \\
\hline & & Up to 25 thousand inhab. $=100 \%$ & \\
\hline & & $>25$ to 50 thousand inhab. $=90 \%$ & \\
\hline & & $>50$ to 100 thousand inhab. $=85 \%$ & \\
\hline & & $>100$ to 500 thousand inhab. $=75 \%$ & \\
\hline & & $>500$ thousand inhab. $=60 \%$ & \\
\hline
\end{tabular}


Analysis and judgment matrix of structural aspects of the evaluation of prenatal care in Primary Care. Brazil, 2017.

\begin{tabular}{|c|c|c|c|}
\hline \multicolumn{4}{|l|}{ Structural aspects } \\
\hline \multicolumn{4}{|l|}{ Human resources } \\
\hline \multirow[t]{7}{*}{ Population coverage } & \multirow[t]{7}{*}{$\%$ population with coverage of the $\mathrm{FHS}^{* * *}$} & \multicolumn{2}{|l|}{ Dichotomous analysis, according to population } \\
\hline & & \multicolumn{2}{|l|}{ size. Parameter to "adequate" (1.0) } \\
\hline & & \multicolumn{2}{|l|}{ Up to 25 thousand inhab. $=100 \%$} \\
\hline & & \multicolumn{2}{|l|}{$>25$ to 50 thousand inhab. $=85 \%$} \\
\hline & & \multicolumn{2}{|l|}{$>50$ to 100 thousand inhab. $=65 \%$} \\
\hline & & \multicolumn{2}{|l|}{$>100$ to 500 thousand inhab. $=55 \%$} \\
\hline & & \multicolumn{2}{|l|}{$>500$ thousand inhab. $=40 \%$} \\
\hline \multirow[t]{3}{*}{ Specialized support } & $\%$ FHS which receives support from experts & \multicolumn{2}{|l|}{$\geq 90 \%=$ adequate $(1.0)$} \\
\hline & & \multicolumn{2}{|l|}{89 to $75 \%$ = minimally adequate $(0.5)$} \\
\hline & & \multicolumn{2}{|l|}{$<75 \%=$ inadequate $(0.0)$} \\
\hline \multicolumn{4}{|r|}{ Both adequate $=$ adequate $(1.0)$} \\
\hline \multirow[t]{6}{*}{ Normatization of care } & $\%$ FHS which uses protocols for prenatal & $\geq 90 \%$ = adequate & Both inadequate $=$ inadequate $(0.0)$ \\
\hline & risk stratification & 89 to $75 \%$ = minimally adequate; & Other situations $=$ little adequate $(0.5)$ \\
\hline & & $<75 \%=$ inadequate & \\
\hline & $\% \mathrm{FHS}$ that has protocols with definition of & \multicolumn{2}{|l|}{$\geq 90 \%$ = adequate } \\
\hline & guidelines to host the pregnant woman & \multirow{2}{*}{\multicolumn{2}{|c|}{$\begin{array}{l}89 \text { to } 75 \%=\text { minimally adequate; } \\
<75 \%=\text { inadequate }\end{array}$}} \\
\hline & & & \\
\hline \multirow[t]{6}{*}{ Updated information } & $\%$ FHS that monthly feed the prenatal & $\geq 90 \%$ = adequate & Both adequate $=$ adequate $(1.0)$ \\
\hline & information system & 89 to $75 \%$ = minimally adequate; & Both inadequate $=$ inadequate $(0.0)$ \\
\hline & & $<75 \%=$ inadequate & Other situations $=$ minimally adequate $(0.5)$ \\
\hline & $\%$ FHS with cytopathological collection & \multicolumn{2}{|l|}{$\geq 90 \%$ = adequate; } \\
\hline & record & \multicolumn{2}{|l|}{89 to $75 \%$ = minimally adequate; } \\
\hline & & \multicolumn{2}{|l|}{$<75 \%=$ inadequate } \\
\hline
\end{tabular}

* Parameters defined according to the tertile distribution for each population size stratum, ** Data collected on the site of the CNES, BHU= Basic Health Unit, FHS= Family Health Strategy. 
Table 2

Analysis and judgment matrix of the operational aspects of the evaluation of prenatal care in Primary Care. Brazil, 2017.

\begin{tabular}{|c|c|c|c|}
\hline Evaluative matrix & Measures & \multicolumn{2}{|c|}{ Judgment parameters } \\
\hline \multicolumn{4}{|l|}{ Operational aspects } \\
\hline \multicolumn{4}{|l|}{ Organization of care } \\
\hline \multirow[t]{3}{*}{ Appropriation of territory } & $\%$ FHS with registration of all pregnant & $\geq 90 \%$ = adequate $(1.0)$ & \\
\hline & women in the territory & 89 to $75 \%=$ minimally adequate $(0.5)$ & \\
\hline & & $<75 \%=$ inadequate $(0.0)$ & \\
\hline \multirow[t]{3}{*}{ Early capture } & $\%$ FHS that perform an active search of & $\geq 90 \%=$ adequate $(1.0)$ & \\
\hline & pregnant women for prenatal care & 89 to $75 \%$ = minimally adequate $(0.5)$ & \\
\hline & & $<75 \%=$ inadequate $(0.0)$ & \\
\hline \multirow[t]{4}{*}{ Adequate access } & $\%$ FHS that have extended working & Dichotomous analysis, according to population & \\
\hline & hours** & size. Parameter for "Adequate" (1.0) & \\
\hline & & Up to 10 thousand inhab. $=100 \%$ & \\
\hline & & $>10$ thousand inhab. $=80 \%$ & \\
\hline \multirow[t]{6}{*}{ Programming of care } & $\%$ FHS that offer scheduled prenatal & $\geq 90 \%$ = adequate & Both Adequate= adequate $(1.0)$ \\
\hline & consultations & 89 to $75 \%$ = minimally adequate; & Both inadequate $=$ inadequate $(0.0)$ \\
\hline & & $<75 \%=$ inadequate & Other situations $=$ little adequate $(0.5)$ \\
\hline & $\%$ FHS that have agenda scheduling & $\geq 90 \%$ = adequate & \\
\hline & according to gestational risk & 89 to $75 \%$ = minimally adequate; & \\
\hline & & $<75 \%=$ inadequate & \\
\hline \multicolumn{4}{|l|}{ Promotion and prevention } \\
\hline \multirow[t]{9}{*}{ Early diagnosis } & $\%$ FHS that request the rapid pregnancy & $\geq 90 \%$ = adequate & All adequate $=$ adequate $(1.0)$ \\
\hline & test & 89 to $75 \%$ = minimally adequate; & All inadequate $=$ inadequate $(0.0)$ \\
\hline & & $<75 \%=$ inadequate & Other situations $=$ minimally adequate $(0.5)$ \\
\hline & $\%$ FHS that request the rapid HIV test & $\geq 90 \%=$ adequate & \\
\hline & & 89 to $75 \%$ = minimally adequate; & \\
\hline & & $<75 \%=$ inadequate & \\
\hline & $\% \mathrm{FHS}$ that request the rapid syphilis test & $\geq 90 \%=$ adequate & \\
\hline & & 89 to $75 \%$ = minimally adequate; & \\
\hline & & $<75 \%=$ inadequate & \\
\hline
\end{tabular}

continue **Parameters defined according to the quartile distribution for each population size stratum, $* * *$ Data collected on the website of Sinasc, BHU $=$ Basic Health Unit, FHS $=$ Family Health Strategy, HIV= Human Immunodeficiency Virus, LB= Live Births. 
Analysis and judgment matrix of the operational aspects of the evaluation of prenatal care in Primary Care. Brazil, 2017.

\begin{tabular}{|c|c|c|c|}
\hline Evaluative matrix & Measures & \multicolumn{2}{|c|}{ Judgment parameters } \\
\hline \multicolumn{4}{|l|}{ Operational aspects } \\
\hline \multicolumn{4}{|l|}{ Promotion and prevention } \\
\hline \multirow{3}{*}{ Immunization } & $\%$ FHS that register the up to date & $\geq 90 \%$ = adequate $(1.0)$ & \\
\hline & vaccination of the pregnant woman & 89 to $75 \%=$ minimally adequate $(0.5)$ & \\
\hline & & $<75 \%=$ inadequate $(0.0)$ & \\
\hline \multirow[t]{6}{*}{ Identification of diseases } & $\%$ FHS that request prenatal exams & $\geq 90 \%=$ adequate & Both adequate $=$ adequate $(1.0)$ \\
\hline & & 89 to $75 \%$ = minimally adequate; & Both inadequate $=$ inadequate $(0.0)$ \\
\hline & & $<75 \%=$ inadequate & Other situations $=$ minimally adequate $(0.5)$ \\
\hline & $\%$ FHS that receive the examinations in a & $\geq 90 \%=$ adequate & \\
\hline & timely manner for necessary & 89 to $75 \%$ = minimally adequate; & \\
\hline & interventions & $<75 \%=$ inadequate & \\
\hline \multirow[t]{3}{*}{ Health education } & $\%$ FHS that offer educational and health & $\geq 90 \%=$ adequate $(1.0)$ & \\
\hline & promotion actions for pregnant women & 89 to $75 \%=$ minimally adequate $(0.5)$ & \\
\hline & & $<75 \%=$ inadequate $(0.0)$ & \\
\hline \multicolumn{4}{|l|}{ Follow-up } \\
\hline \multirow[t]{3}{*}{ Follow-up of the gestational cycle } & Proportion of LB of mothers with seven & $\geq 90 \%=$ adequate $(1.0)$ & \\
\hline & or more prenatal visits*** & 89 to $75 \%=$ minimally adequate $(0.5)$ & \\
\hline & & $<75 \%=$ inadequate $(0.0)$ & \\
\hline \multirow[t]{6}{*}{ Reference and counter-reference } & $\%$ FHS that maintains a register of higher & $\geq 90 \%=$ adequate & Both adequate $=$ adequate $(1.0)$ \\
\hline & risk pregnant women referred to other & 89 to $75 \%$ = minimally adequate; & Both inadequate $=$ inadequate $(0.0)$ \\
\hline & points of care & $<75 \%=$ inadequate & Other situations $=$ minimally adequate $(0.5)$ \\
\hline & $\%$ FHS that receive the counter-referral & $\geq 90 \%=$ adequate & \\
\hline & of maternity hospitals & 89 to $75 \%$ = minimally adequate; & \\
\hline & & $<75 \%=$ inadequate & \\
\hline \multirow[t]{3}{*}{ Continuity of care } & $\%$ FHS which conducted puerperium & $\geq 90 \%$ = adequado & \\
\hline & consultations up to 10 days after delivery & 89 a $75 \%$ = pouco adequado; & \\
\hline & & $<75 \%=$ inadequado & \\
\hline
\end{tabular}

**Parameters defined according to the quartile distribution for each population size stratum, ***Data collected on the website of Sinasc, BHU= Basic Health Unit, FHS= Family Health Strategy, HIV= Human Immunodeficiency Virus, LB= Live Births. 
In addition to the PMAQ - AB database, the official sites of the Live Birth Information System (Sinasc), the National Registry of Health Establishments (CNES) and the Brazilian Institute of Geography and Statistics (IBGE) were used as sources of evidence.

The parameters for the issuing of value judgments that guided the descriptive analysis were defined based on literature review, documentary research and the fact that all actions chosen were well founded, based on scientific evidence and recommended in official documents for at least five years. (Tables 1 and 2).

In the analysis of the measures it was considered adequate when in the municipality at least $90 \%$ of the BHU or FHS teams performed the action (s); inadequate when less than $75 \%$ of the BHU or FHS teams performed the action (s); and minimally adequate, in the rest of the cases. There was an exception in four measures: for minimum adequate FHS team, FHS teams with oral health and population coverage, the parameters were defined by population size, by tertile distribution, and for extended hours of operation, they were also defined by population size, but by quartile distribution.

Data were analyzed using Microsoft Office Excel $^{\circledR}$ and SPSS 22.0 software and presented in tabular form

For indicators with more than one measure it was considered adequate when all measures were classified as adequate, inadequate when all measures were classified as inadequate and the other situations, as minimally adequate.

Initially, measures and indicators were analyzed and, in the aftermath, the conversion into scores 1.0 (adequate) 0.5 (a) and 0.0 (inadequate) was made. The analysis was guided by the sum of the scores, followed by the calculation of the percentage of points obtained compared to the maximum score expected in each of the components, as follows: ( $\Sigma$ obtained / $\Sigma$ expected) x100. For the value judgment of dimensions, the cut-off points used were: adequate (100\%-75\% of the expected), inadequate (less than or equal to $50 \%$ of the expected) and the other cases were minimally adequate, received weight two, considering it with greater influence on the adequacy of attention.

The study was approved by the Human Research Ethics Committee of the Federal University of Santa Catarina (CEPSH/UFSC), Opinion $n^{\circ} 1.599 .464$
CAAE nº 53671016.1.1001.0121.

\section{Results}

The study analyzed $72.9 \%$ of the total number of Brazilian municipalities, predominantly with a population size of less than 25 thousand inhabitants (78.8\%), with less than one quarter (24.6\%) presenting an adequate prenatal care.

In Table 3, it is observed that the structural aspects dimension $39.1 \%$ of the municipalities was classified as minimally adequate. In the analysis of the infrastructure, the physical space presented more than half of the adequate municipalities (69.6\%). Regarding human resources, a positive highlight was the specialized support with $86.4 \%$ of the municipalities offering specialist support to the PC teams and for the population coverage that showed adequacy in $53.3 \%$ of the municipalities. The standardization of care was the subdimension with the highest percentage of inadequate municipalities $(62.0 \%)$, especially in the standardization of care indicator.

The classification in the dimension of operational aspects was minimally adequate in $49.1 \%$ of the municipalities. In the organization of the care, the appropriation of the territory $(82.3 \%)$ and the early capture $(56.9 \%)$ were indicators with the highest percentages of adequacy. While in the access indicator $63.9 \%$ of the municipalities were inadequate, that is, they do not have health units with an extended working period. In the analysis of promotion and prevention actions, a low percentage of municipalities $(22.6 \%)$ presented adequacy in the early diagnosis of pregnancy, HIV and syphilis. In the follow-up subdimension, most municipalities $(58.7 \%)$ were inadequate, especially in gestational follow-up (64.8\%). In contrast, the continuity of care is within the expected level in $74.9 \%$ of the municipalities.

With regard to the population size and regional location (Tables 4 and 5), municipalities with up to 10,000 inhabitants achieved better results in structural aspects $(50.8 \%)$, operational aspects $(38.6 \%)$ and general prenatal evaluation (41.6\%), compared to the others. Regarding location, the worst results were observed in the North region in all items analyzed. The Southeast region presented adequacy in operational aspects and the South region in structural aspects and the general prenatal evaluation. 
Table 3

Classification of municipalities in the evaluation of prenatal care in Primary Care according to components, dimensions and subdimensions. Brazil, 2017.

\begin{tabular}{|c|c|c|c|c|c|c|}
\hline \multirow{2}{*}{ Components } & \multicolumn{2}{|c|}{ A } & \multicolumn{2}{|c|}{ LA } & \multicolumn{2}{|c|}{ I } \\
\hline & $\mathrm{n}$ & $\%$ & $\mathrm{n}$ & $\%$ & $\mathrm{n}$ & $\%$ \\
\hline Structural Aspects & 1323 & 32.6 & 1587 & 39.1 & 1149 & 28.3 \\
\hline Infrastructure & 1442 & 35.5 & 1130 & 27.8 & 1487 & 36.6 \\
\hline Adequacy of physical space & 2825 & 69.6 & 485 & 11.9 & 749 & 18.5 \\
\hline Materials and equipment & 1735 & 42.7 & 2040 & 50.3 & 284 & 7.0 \\
\hline Inputs and medicines & 1116 & 27.5 & 1898 & 46.8 & 1045 & 25.7 \\
\hline Human Resources & 1515 & 37.3 & 1063 & 26.2 & 1481 & 36.5 \\
\hline Staff Adequacy & 1476 & 36.4 & 1542 & 38.0 & 1041 & 25.6 \\
\hline Population coverage & 2164 & 53.3 & - & - & 1895 & 46.7 \\
\hline Specialized Support & 3509 & 86.4 & 273 & 6.7 & 277 & 6.8 \\
\hline Standardization of care & 1543 & 38.0 & - & - & 2516 & 62.0 \\
\hline Normatization of care & 900 & 22.2 & 1557 & 38.4 & 1602 & 39.5 \\
\hline Updated information & 1811 & 44.6 & 2030 & 50.0 & 218 & 5.4 \\
\hline Operational Aspects & 977 & 24.1 & 1994 & 49.1 & 1088 & 26.8 \\
\hline Organization of care & 1956 & 48.2 & 704 & 17.3 & 1399 & 34.5 \\
\hline Appropriation of territory & 3340 & 82.3 & 321 & 7.9 & 398 & 9.8 \\
\hline Early Capture & 2310 & 56.9 & 563 & 13.9 & 1186 & 29.2 \\
\hline Adequate access & 1464 & 36.1 & - & - & 2595 & 63.9 \\
\hline Programming of care & 2226 & 54.8 & 1515 & 37.3 & 318 & 7.8 \\
\hline Promotion and prevention & 1985 & 48.9 & 823 & 20.3 & 1251 & 30.8 \\
\hline Early diagnosis & 916 & 22.6 & 1668 & 41.1 & 1475 & 36.3 \\
\hline Immunization & 3401 & 83.8 & 312 & 7.7 & 346 & 8.5 \\
\hline Identification of diseases & 1670 & 41.1 & 1972 & 48.6 & 417 & 10.3 \\
\hline Health education & 2451 & 60.4 & 561 & 13.8 & 1047 & 25.8 \\
\hline Follow-up & 551 & 13.6 & 1125 & 27.7 & 2383 & 58.7 \\
\hline Gestational follow-up & 185 & 4.6 & 1244 & 30.6 & 2630 & 64.8 \\
\hline Reference and counter-reference & 1093 & 26.9 & 2737 & 67.4 & 229 & 5.6 \\
\hline Continuity of care & 3041 & 74.9 & 462 & 11.4 & 556 & 13.7 \\
\hline General Evaluation of Prenatal Care & 997 & 24.6 & 2153 & 53.0 & 909 & 22.4 \\
\hline
\end{tabular}

$A=$ Adequate, $L A=$ Minimally adequate, $I=$ Inadequate. 
Evaluation of structural, operational aspects and overall evaluation of prenatal care in Primary Care, according to population size. Brazil, 2017.

\begin{tabular}{|c|c|c|c|c|c|c|c|}
\hline \multirow{2}{*}{ Population size (inhabitants) } & \multicolumn{2}{|c|}{ A } & \multicolumn{2}{|c|}{ LA } & \multicolumn{2}{|c|}{ I } & \multirow{2}{*}{$p$} \\
\hline & $\mathrm{n}$ & $\%$ & $\mathrm{n}$ & $\%$ & $\mathrm{n}$ & $\%$ & \\
\hline Structural aspects & & & & & & & $<0.001$ * \\
\hline Up to 10 thousand & 990 & 50.8 & 692 & 35.5 & 267 & 13.7 & \\
\hline 10 to 25 thousand & 214 & 17.1 & 569 & 45.6 & 466 & 37.3 & \\
\hline 25 to 50 thousand & 64 & 13.6 & 176 & 37.5 & 229 & 48.8 & \\
\hline$>50$ thousand & 55 & 14.0 & 150 & 38.3 & 187 & 47.7 & \\
\hline Operational aspects & & & & & & & $<0.001$ * \\
\hline Up to 10 thousand & 752 & 38.6 & 854 & 43.8 & 343 & 17.6 & \\
\hline 10 to 25 thousand & 120 & 9.6 & 677 & 54.2 & 452 & 36.2 & \\
\hline 25 to 50 thousand & 51 & 10.9 & 247 & 52.7 & 171 & 36.5 & \\
\hline$>50$ thousand & 54 & 13.8 & 216 & 55.1 & 122 & 31.1 & \\
\hline General evaluation of prenatal care & & & & & & & $<0.001 *$ \\
\hline Up to 10 thousand & 810 & 41.6 & 876 & 44.9 & 263 & 13.5 & \\
\hline 10 to 25 thousand & 106 & 8.5 & 760 & 60.8 & 383 & 30.7 & \\
\hline 25 to 50 thousand & 41 & 8.7 & 273 & 58.2 & 155 & 33.0 & \\
\hline$>50$ thousand & 40 & 10.2 & 244 & 62.2 & 108 & 27.6 & \\
\hline
\end{tabular}

*Pearson's Chi-square test, $\mathrm{A}=$ Adequate, $\mathrm{LA}=$ Minimally adequate, $\mathrm{I}=$ Inadequate.

\section{Table 5}

Evaluation of structural, operational aspects and overall evaluation of prenatal care in Primary Care, according to regions. Brazil, 2017.

\begin{tabular}{|c|c|c|c|c|c|c|c|}
\hline \multirow{2}{*}{ Regions } & \multicolumn{2}{|c|}{ A } & \multicolumn{2}{|c|}{ LA } & \multicolumn{2}{|c|}{1} & \multirow{2}{*}{$p$} \\
\hline & $\mathrm{n}$ & $\%$ & $\mathrm{n}$ & $\%$ & $\mathrm{n}$ & $\%$ & \\
\hline Structural aspects & & & & & & & $<0.001 *$ \\
\hline North & 61 & 22.7 & 84 & 31.2 & 124 & 46.1 & \\
\hline Northeast & 431 & 34.2 & 576 & 45.6 & 255 & 20.2 & \\
\hline Center-west & 95 & 24.1 & 156 & 39.6 & 143 & 36.3 & \\
\hline Southeast & 393 & 31.8 & 477 & 38.6 & 367 & 29.7 & \\
\hline South & 343 & 38.2 & 294 & 32.8 & 260 & 29.0 & \\
\hline Operational aspects & & & & & & & $<0.001 *$ \\
\hline North & 33 & 12.3 & 133 & 49.4 & 103 & 38.3 & \\
\hline Northeast & 143 & 11.3 & 707 & 56.0 & 412 & 32.6 & \\
\hline Center-west & 87 & 22.1 & 202 & 51.3 & 105 & 26.6 & \\
\hline Southeast & 420 & 34.0 & 535 & 43.2 & 282 & 22.8 & \\
\hline South & 294 & 32.8 & 417 & 46.5 & 186 & 20.7 & \\
\hline General evaluation of prenatal care & & & & & & & $<0.001 *$ \\
\hline North & 39 & 14.5 & 133 & 49.4 & 97 & 36.1 & \\
\hline Northeast & 180 & 14.3 & 773 & 61.3 & 309 & 24.5 & \\
\hline Center-west & 89 & 22.6 & 201 & 51.0 & 104 & 26.4 & \\
\hline Southeast & 386 & 31.2 & 619 & 50.0 & 232 & 18.8 & \\
\hline South & 303 & 33.8 & 427 & 47.6 & 167 & 18.6 & \\
\hline
\end{tabular}

*Pearson's Chi-square test, $A=$ Adequate, $L A=$ Minimally adequate, $\mathrm{I}=$ Inadequate. 


\section{Discussion}

The analysis of this study reveals relevant data on prenatal care under the responsibility of Brazilian municipalities. Less than a quarter of the municipalities presented prenatal adequacy in PC, with worse conditions in the ones with larger population size and located in the North region.

Between the two dimensions analyzed, the structural aspects presented a greater number of municipalities classified as adequate. In the infrastructure analysis, financial incentives from the Ministry of Health offered to municipalities since 2011 for the reform, expansion and construction of BHU could have contributed to the result of adequacy of the physical space, with a view to improving working conditions, access and quality of PC. 12

The high percentage of municipalities offering specialized support is another positive aspect in this dimension, since a care network must be activated in cases that exceed the competencies of the PC teams. In this network are the Family Health Support Center (NASF) and specialists who provide matrix support and care, fundamental to ensure qualified and resolutive clinical action. However, as in other studies, 11,13 problems were identified in the adequacy of personnel and population coverage. These are extremely important factors in ensuring that the demands of the population are met without increased workload and with a satisfactory teampopulation relationship. 14

In the subdimension of standardization of care, most municipalities were inadequate, differing from the findings of Luz et al.6. It is worth mentioning that the authors analyzed the availability of protocols, unlike the measure adopted in this study that included the information of its use. Municipal management needs to standardize care and encourage teams with respect to the use of clinical protocols for safe decision-making and quality in the care for pregnant women in all units and health services.

Operational aspects are fundamental for the comprehensive and equitable care of the mother/ baby binomial. In the organization of care, teams must provide access and adherence to health services. Teams from the municipalities studied, mostly, have information of the territory, make early capture and offer scheduled appointments, according to the gestational risk. Such strategies are fundamental for continuous follow-up with a view to reducing risks and possible complications for the pregnant woman and the fetus. 14,15 However, access to the BHU was inadequate, with almost two-thirds of the municipalities without an alternative schedule of care for the pregnant worker. Similar findings were reported by Silva MZN et al. 15 corroborating the observation that the non-expansion of the opening hours of the units makes it difficult for pregnant women to access the service, as well as it threats their right to health.

Promotion and prevention actions ensure general health and well-being in the gestational period and include: early diagnosis, immunization, identification of diseases and health education. The findings on early diagnosis in this study deserve attention. Confirmation of pregnancy in the first months allows continuous follow-up, with more guidance and consultation, possibility of identification and appropriate treatment of diseases. Rapid tests of HIV and syphilis allow the immediate onset of follow-up as well as the prevention of vertical transmission of these diseases. The increase in the number of cases, especially syphilis in Brazil, reinforces the concern and demonstrates the importance of qualified prenatal care in PC. 16

Women should be followed throughout the gestational and puerperal cycle, at different points in the network. The ideal number of consultations is a controversial topic, but it is a frequent indicator in studies evaluating prenatal care. Some countries consider four, six, ten and can reach 15 consultations, as in Finland.17

In 2016, the World Health Organization (WHO) expanded the number of consultations from four to eight, based on the scientific evidence that related the increase in the number of meetings with a lower probability of stillborn children.1 In Brazil, the last recommendation, defined in 2011 , is at least seven prenatal consultations, and was used in this analysis. The prevalence of accomplishment of seven or more prenatal visits has increased in the country over the years, from $43.7 \%$, in 2000 , to $61.1 \%$, in $2010.18-21$ Despite advances, more than half of municipalities $(64.8 \%)$ were inadequate in this indicator, considering the judgment parameter defined in this study.

Follow-up at different points in the network has been regular in most municipalities and its effects on the monitoring of high-income pregnant women and the return from maternity are a concerning issue. On the other hand, postpartum care continuity was adequate in most municipalities. Nearly three-quarters of the municipalities have at least $90 \%$ of the teams performing puerperal consultation until the $10^{\text {th }}$ day following the birth, similar to what was found by other authors. 22,23 Concerning about the baby's health, calendar for vaccinations and early diagnosis tests, such as that of the foot, contribute to 
the return of puerperae to the unit during this period, and may justify the high percentage of adequacy of this indicator. Measures to improve network integration must be implemented in order to increase safety and improve outcomes in the follow-up of pregnant women.

The municipalities with larger population size showed the worst results compared to smaller ones, corroborating studies at the national level. Larger municipalities have more difficulties in equating public policy actions, while smaller ones are able to meet the basic needs of the population more easily. 24,25 As well as that found by other researchers, 4,11 the North region was the one that presented the worst results, requiring a development model committed to the reduction of regional inequalities and integration between levels of health care, combined with economic and social policies geared towards social inclusion.

In this study, an evaluation of prenatal care in PC was conducted with data from the PMAQ, using Brazilian municipalities as the unit of analysis. Limitations such as the use of secondary data made it difficult the deepening of the analysis. On the other hand, the exploration of data collected with public resources, in a research that adopted a qualified methodological process, is desirable. In the PMAQ, data collection is done with prior sche- duling, interviewees are aware of the content of questions and it also provides financial contribution to the municipalities that meet established goals. Therefore, it would be expected to find slightly better results, which allows us to affirm that, in fact, data presented here can represent the Brazilian reality.

The reduction of maternal and child mortality rates is a global goal and it has been demanding from the managers actions that ensure equitable public policies and the strengthening of regional networks of care focused on social inclusion for decades. 26

Most of municipalities in the country presented a low adequacy in prenatal care, even though the performance was better in structural aspects. It is recommended periodic prenatal evaluations to follow up and adopt measures that will improve the quality of this care.

\section{Authors' Contribution}

Cunha AC e Lacerda JT - preparation of the manuscript, search in databases, data collection and analysis, writing, conducting and review. Alcauza MTR and Natal S - writing and review of the manuscript. All authors have approved the final version of the manuscript.

\section{References}

1. World Health Organization (WHO). WHO recommendations on antenatal care for a positive pregnancy experience. Geneva: WHO; 2016. [acesso em 26 jan 2019]. Disponível em: https://apps.who.int/iris/bitstream/handle/10665/ 250796/9789241549912eng.pdf;jsessionid=18BB411AA9F 40CFF591B9F90322FBA65? sequence $=1$

2. Brasil. Ministério da Saúde. Secretaria de Atenção à Saúde. Departamento de Ações Programáticas Estratégicas. Política Nacional de Atenção Integral à Saúde da Criança: orientações para implementação / Ministério da Saúde. Brasília, DF; 2018. 180 p.:il.

3. Sena IVA. Qualidade da Atenção Pré-Natal na Estratégia Saúde da Família: Revisão de Literatura. [internet]; 2014 [acesso em 19 jan 2019]. Disponível em: https://www.nescon.medicina.ufmg.br/biblioteca/imagem/4 555.pdf.

4. Tsunechiro MA, Lima MOP, Bonadio IC, Corrêa MD, Silva AVA, Donato SCT. Avaliação da assistência pré-natal conforme o Programa de Humanização do Pré-natal e Nascimento. Rev Bras Saúde Mater Infant. 2018; 18 (4): 781-90.

5. Heaman MI, Martens PJ, Brownell MD, Chartier MJ, Derksen SA, Helewa ME. The Association of Inadequate and Intensive Prenatal Care With Maternal, Fetal, and
Infant Outcomes: A Population-Based Study in Manitoba, Canada. J Obstet Gynaecol Can. 2019. (No prelo).

6. Luz LA, Aquino R, Medina MG. Avaliação da qualidade da Atenção Pré-Natal no Brasil. Saúde debate. 2018; 42 (n. spe2): 111-26.

7. Nunes JT, Gomes KRO, Rodrigues MTP, Mascarenhas MDM. Qualidade da assistência pré-natal no Brasil: revisão de artigos publicados de 2005 a 2015. Cad Saúde Colet. 2016; 24 (2): 252-61.

8. França EB, Lansky S, Rego, MAS, Malta DC, França JS, Teixeira R. Principais causas da mortalidade na infância no Brasil, em 1990 e 2015: estimativas do estudo de Carga Global de Doença. Rev Bras Epidemiol (online). 2017; 20 (Suuppl 1): 46-60.

9. Brasil. Ministério da Saúde. Departamento de Informática do Sistema Único de Saúde -DATASUS. Informação sobre nascidos vivos e óbitos maternos do ano de 2016. [acesso em 13 jul 2018]. Disponível em: http://www2.datasus. gov.br/DATASUS/index.php?area $=0205 \& \mathrm{id}=6939 \& \mathrm{VObj}=$ http://tabnet.datasus.gov.br/cgi/deftohtm.exe?sim/cnv/mat1 0 . 
10. Guimaraes WSG, Parente RCP, Guimaraes TLF, Garnelo L. Acesso e qualidade da atenção pré-natal na Estratégia Saúde da Família: infraestrutura, cuidado e gestão. Cad Saúde Pública. 2018; 34 (5): e00110417.

11. Tomasi E, Fernandes PAA, Fischer T, Siqueira FCV, Silveira DS, Thumé E, Duro SMS, Saes MO, Nunes BP, Fassa AG, Facchini, LA. Qualidade da atenção pré-natal na rede básica de saúde do Brasil: indicadores e desigualdades sociais. Cad Saúde Pública. 2017; 33 (3): e00195815.

12. Brasil. Diário Oficial. Portaria $n^{\circ} 2.488$, de 21 de outubro de 2011. Aprova a Política Nacional de Atenção Básica, estabelecendo a revisão de diretrizes e normas para a organização da Atenção Básica, para a Estratégia Saúde da Família (ESF) e o Programa de Agentes Comunitários de Saúde (PACS). Brasília, DF; n.204, p.55, 24 out. 2011; Seção $1, \mathrm{pt} 1$

13. Viellas EF, Domingues RM, Dias MA, Gama SG, Theme Filha MM, Costa JV, Bastos, MH, Leal, MC. Assistência pré-natal no Brasil. Cad Saúde Pública. 2014; 30 (Suppl. 1): $\mathrm{S} 85-\mathrm{S} 100$

14. Faria HP, Werneck MAF, Santos AS, Teixeira PF. Processo de trabalho em saúde: protocolo de cuidado à saúde e organização do serviço. 2 ed. Belo Horizonte: COOPMED; 2009 .

15. Silva MZN, Andrade AB, Bosi MLM. Acesso e acolhimento no cuidado pré-natal à luz de experiências de gestantes na Atenção Básica. Saúde Debate. 2014; 38 (103) 805-16.

16. Cruz RSBLC, Caminha MFC, Filho MB. Aspectos históricos, conceituais e organizativos do Pré-natal. Rev Bras Saúde. 2014; 18(1): 87-94.

17. Silva EP, Lima RT, Costa MJC, Batista Filho M Desenvolvimento e aplicação de um novo índice para avaliação do pré-natal. Rev Panam Salud Pública. 2013; 33 (5): 356-62.

18. César JA, Mendonza-Sassi RA, Gonzalez-Chica DA, Mano PS, Goulart Filho SM. Características sociodemográficas e de assistência à gestação e ao parto no extremo sul do Brasil. Cad Saúde Pública. 2011; 27 (5): 985-94.
19. Anversa ETR, Bastos GAN, Nunes LN, Dal Pizzol TDS. Qualidade do processo da assistência pré-natal: unidades básicas de saúde e unidades de Estratégia Saúde da Família em município no Sul do Brasil. Cad Saúde Pública. 2012; 28 (4): 789-800

20. Brasil. Ministério do Planejamento, Orçamento e Gestão. Instituto Brasileiro de Geografia e Estatística (IBGE). Diretoria de Pesquisas. Coordenação de População e Indicadores Sociais. Estudos e Pesquisas: informação demográfica e socioeconômica número 32. Síntese de Indicadores Sociais: uma análise das condições de vida da população brasileira 2013. Rio de Janeiro: IBGE; 2013.

21. Anjos JC, Boing AF. Diferenças regionais e fatores associados ao número de consultas de pré-natal no Brasil: análise do Sistema de Informações sobre Nascidos Vivos em 2013. Rev Bras Epidemiol. 2016; 19 (4): 835-50.

22. Oliveira RLA, Fonseca CRB, Carvalhaes MABL, Parada CMGL. Avaliação da atenção pré-natal na perspectiva dos diferentes modelos na atenção primária. Rev Latino-Am Enfermagem. 2013; 21 (2): 1-8.

23. Corrêa MD, Tsunechiro MA, Lima MOP, Bonadio IC. Avaliação da assistência pré-natal em unidade com estratégia saúde da família. Rev Esc Enferm USP. 2014; 48 (Esp): 24-32

24. Calvo MCM, Lacerda JT, Colussi CF, Schneider IJC, Rocha TAH. Estratificação de municípios brasileiros para avaliação de desempenho em saúde. Epidemiol Serv Saúde. 2016; 25 (4): 767-76.

25. Domingues RMSM, Viellas, EF, Dias, MAB, Torres JÁ, Theme-Filha MM, Gama SGN, Leal, MC. Adequação da assistência pré-natal segundo as características maternas no Brasil. Rev Panam Salud Pública. 2015; 37 (3): 140- 7.

26. Dourado DA, Elias PEM. Regionalização e dinâmica política do federalismo sanitário brasileiro. Rev Saude Pública. 2011; 45 (1): 204-11.

Received on August 15, 2018

Final version presented on April 25, 2019

Approved on May 09, 2019 